\title{
Arbitrarily primed-polymerase chain reaction (AP-PCR) typing of Clostridium difficile isolated from different sources of Imam Reza hospital, Tabriz, Iran
}

\author{
Mohammad Taghi Akhi ${ }^{1}$, Mohammad Aghazadeh ${ }^{1}$, Naser Eivazian Kary ${ }^{2}$, Masoud Darabi ${ }^{3}$, \\ Mohammad Hosein Soroush barhagi ${ }^{1}$ and Tahereh Pirzadeh ${ }^{1 *}$
}

${ }^{1}$ Department of Microbiology, Faculty of Medicine, Tabriz University of Medical Science, Iran.

${ }^{2}$ Department of Plant Protection, Faculty of Science, Azarbaijan University of Tarbiat Moallem

Tabriz, Iran.

${ }^{3}$ Department of Clinical Biochemistry, Faculty of Medicine, Tabriz University of Medical Science, Iran.

Accepted 30 April, 2013

\begin{abstract}
Detection of the source of Clostridium difficile for the control of nosocomial infections produced by these bacteria is very important. For this reason $84 \mathrm{C}$. difficile isolated from 250 stool samples of symptomatic patients, staff, asymptomatic patients at first day of admission, the same patients after seven days of hospitalization and 135 samples from their hospital environment were typed by AP- PCR. In addition to conventional standard tests, gas liquid chromatography was also used as complementary test to identify $C$. difficile isolates. All isolates were separated into 12 genotypes, with $31 \%$ falling into group I. Genotypes VIII, X and XII were found only in isolates of symptomatic patients while genotype I was observed in all $C$. difficile of patients and environment. Genotypes III was not detected in any $C$. difficile isolates except in one of the acquired isolates. $C$. difficile is frequently transmitted among hospitalized patients, staff, and their hospital environment.
\end{abstract}

Key words: Clostridium difficile, arbitrarily primed- PCR, gas chromatography.

\section{INTRODUCTION}

Clostridium difficile is one of the major cause of nosocomial acquired antibiotic-associated diarrhea and pseudomembranous colitis (Noren, 2010; Conly, 2000) and is an important financial burden on modern hospitals (Conly, 2000). Although it has been established that certain antibiotics, particularly second and third generation cephalosporins increase the risk of infection to C. difficile (Conly, 2000), it is important that exposure of hospitalized patients to sources of $C$. difficile is minimized. Numerous $C$. difficile reservoirs exist within hospitals, including contaminated environmental surfaces of different wards (Hota, 2004; Mayfield et al., 2000). Environmental contamination with $C$. difficile spores occurs as many as 34 to $58 \%$ of sites despite cleaning, with surfaces of fomites being most frequently contaminated (Boyce, 2007), normal hospital staff carriage (Kim et al., 1981), colonized new admitted patients (Muto, 2007) and aerial dissemination (Roberts et al., 2008). This huge potential and diverse source provides simple facilities for infection of patients who are under antibiotic therapy. In order to understand the epidemiology of outbreaks and isolated cases, to identify any possible incidence of cross infection, typing of $C$. difficile is necessary. There are several phenotypic and genotypic typing methods (Brazier, 2001). AP-PCR is a simple and suitable technique that has been used 
successfully for typing of $C$. difficile in recent years (Killgore and Kato, 1994; Martirosian et al., 1995; Bidet et al., 2000; Rafferty et al., 1998). In this method a single primer approximately 10 nucleotides in length with arbitrary sequence is used. The aim of this study was to compare $C$. difficile isolated from different sources within a general hospital in North West of Iran by AP-PCR.

\section{MATERIALS AND METHODS}

\section{Collection of specimens}

Eighty-four $C$. difficile isolates recovered from 250 stool samples of symptomatic patients $(14 / 50)$, staff $(18 / 100)$, asymptomatic patients at first day of admission (16/50), the same patients after seven days of hospitalization $(6+16 / 50)$ and from 135 samples of their hospital environment (14/135). Ten wards of Imam Reza hospital including, nephrology, gastroenterology, pulmonology, endocrine and rheumatology, neurology, infectious disease, ICU of neurology, ICU of neurology surgery, ICU of general surgery and ICU of pulmonary were chosen based on the length of patients hospitalization. The Imam Reza hospital is situated in Tabriz city with 520 beds in 26 clinical wards, providing services for nearly two thousand patients monthly.

C. difficile were cultured from collected samples by three standard techniques (using Anoxomat: MART Microbiology B.V. the Netherlands $0 \% \mathrm{O}_{2}, 10 \% \mathrm{H}_{2}, 10 \% \mathrm{CO}_{2}, 80 \% \mathrm{~N}_{2}$ ) and suspicious colonies with specific horse odor, characteristic morphology of colonies were identified by conventional biochemical tests as previously described (Akhi et al., 2011).

\section{Gas-liquid chromatography (GLC)}

Gas chromatography as complementary test was also used to further identification of $C$. difficile by determination of the volatile short- chain fatty acids (isocaproic acid and isovaleric acid) produced by the growth of $C$. difficile (Johnson et al., 1989; Pepersack et al., 1983). A $48 \mathrm{~h}$ growth in thioglycolate broth medium were used to extract volatile fatty acids by adding $0.2 \mathrm{ml}$ of $\mathrm{H}_{2} \mathrm{SO}_{4}(50 \%)$ and $1 \mathrm{ml}$ of ethyl ether to $1 \mathrm{ml}$ of the well-mixed culture broth medium. These mixtures were inverted gently several times and centrifuged briefly to separate the phases. One microliter sample of the ether phase was injected into the chromatograph. Volatile fatty acid were separated on a $60 \mathrm{~m} \times 0.25 \mathrm{~mm}$ Teknokroma TR CN100 column using a Buck Scientific model 610 gas chromatograph equipped with a split injector and a flame ionization detector. Helium was used as the carrier gas and column linear velocity was set at $20.0 \mathrm{~cm} / \mathrm{s}$ and the oven temperature at $150^{\circ} \mathrm{C}$. The oven temperature program was isothermal for $20 \mathrm{~min}$ (Johnson et al., 1989; Pepersack et al., 1983) retention times were identified by injecting known standards (Sigma chemicals).

\section{DNA fingerprinting}

Fingerprinting of the $84 C$. difficile DNA isolates were carried out by arbitrarily primed PCR (AP- PCR). Samples were prepared from overnight growth of $C$. difficile isolates on pre-reduced Columbia agar with $5 \%$ sheep blood. DNA of isolates was extracted by sodium dodecyl sulphate- proteinase $\mathrm{K}$ modified with $\mathrm{N}, \mathrm{N}$, Ntrimethyl ammonium bromide (Nikbakht et al., 2008). We chose the ARB11 primer with the sequence of 5'-CTAGGACCGC-3' because it gives clear differences among isolates of $C$. difficile (Fawley and Wilcox, 2001).

\section{Amplification conditions}

The total volume of PCR mix was $50 \mu$ including: 10X PCR buffer 5 $\mu \mathrm{l}$, dNTP mix $(10 \mathrm{mM}) 1 \mu \mathrm{l}, \mathrm{MgCl}_{2}(50 \mathrm{mM}) 5 \mu \mathrm{l}$, primer $(10 \mathrm{pmol}) 2$ $\mu \mathrm{l}$, Taq DNA polymerase $(5 \mathrm{U} / \mu \mathrm{l}) 0.2 \mu \mathrm{l}$, template DNA $2 \mu \mathrm{l}$, sterile redistilled $\mathrm{H}_{2} \mathrm{O} 34.8 \mu \mathrm{l}$. Negative control contained all components except template DNA (Fawley and Wilcox, 2001). The primer and other reagents were prepared according to the manufacturer's recommendations (Cinnagen, Fermentas). PCR reactions were performed with an automated thermal cycler (Eppendorf mastercycler gradient, Germany) with the PCR cycling conditions of initial cycle at $94^{\circ} \mathrm{C}$ for four minutes, 40 cycles of denaturation at $94^{\circ} \mathrm{C}$ for one minute, annealing at $30^{\circ} \mathrm{C}$ for one minute, extension at $72^{\circ} \mathrm{C}$ for two minutes, and final cycle extension at $72^{\circ} \mathrm{C}$ for 5 minutes. Amplified DNA was separated by $1.2 \%$ agarose gel electrophoresis using Tris-borate EDTA ( 1x TBE) buffer $\mathrm{pH} 8$ for 2 $\mathrm{h}$ at $100 \mathrm{~V}$. Eight microliter of PCR products were mixed with $2 \mu \mathrm{l}$ of $6 x$ loading buffer $(10 \mathrm{mM}$ Tris- $\mathrm{Hcl}, 0.03 \%$ bromophenol blue, $0.03 \%$ xylene cyanol , $60 \%$ glycerol and $60 \mathrm{mM}$ EDTA ) and filled into the wells. We used $1 \mathrm{Kbp}$ DNA Ladder for estimation of the size of PCR products (Fermentas). After electrophoresis the gels were stained in $0.5 \mu \mathrm{g} / \mathrm{ml}$ of ethidium bromide solution for $15 \mathrm{~min}$. DNA profiles were visualized by means of ultraviolet (UV) light on a UV transiluminator. The gels were photographed using a gel documentation system (UVP, USA) for the analysis of bands. The banding patterns of all lanes were visually compared, and isolates showing identical patterns or variation only in very faint bands were considered the same type.

\section{RESULTS}

Detection of isocaproic and isovaleric acids has been suggested as a screening test for $C$. difficile in stools (Johnson et al., 1989; Pepersack et al., 1983). Thus, gas chromatographic results for $84 \mathrm{C}$. difficile isolates, already identified by conventional standard tests, were evaluated with respect to isocaproic and isovaleric acids production. Chromatogram for two volatile fatty acids and for standard C. difficile strain ATCC 43593 is shown in Figure $1 \mathrm{a}$ and $\mathrm{b}$. All $84 \mathrm{C}$. difficile isolated from different sources exhibited this characteristic pattern of peaks, which included isovaleric and isocaproic acids Figure 1c. Amounts of other fatty acids were also present. The nonC. difficile clostridia were easily differentiated from $C$. difficile, as they did not produce the same variety or abundance of these fatty acids.

\section{Arbitrarily primed PCR (AP-PCR)}

AP-PCR separated the 84 examined isolates into twelve genotypes, numbered I to XII. The frequency of different genotypes among isolates were genotypes I (31\%), IV $(19.1 \%), \mathrm{XI}(9.5 \%), \mathrm{V}$ and $\mathrm{VII}(8.3 \%), \mathrm{VI}$ and IX (7.1\%), VIII (4.8\%), XII, X, III and II (1.2\%) respectively (Table 1). Genotypes I to XII for $C$. difficile isolated from staff, hospital environments, asymptomatic patients at first day of admission, the same patients after seven days of hospitalization, and symptomatic patients are shown separately in Figure 2.

Out of $14 \mathrm{C}$. difficile isolated from environment, three 


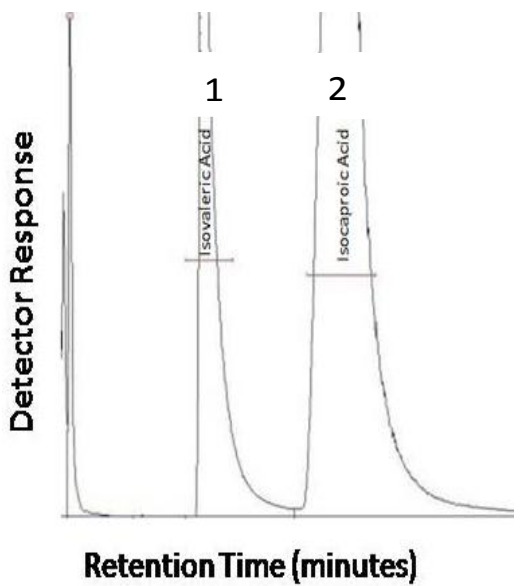

A

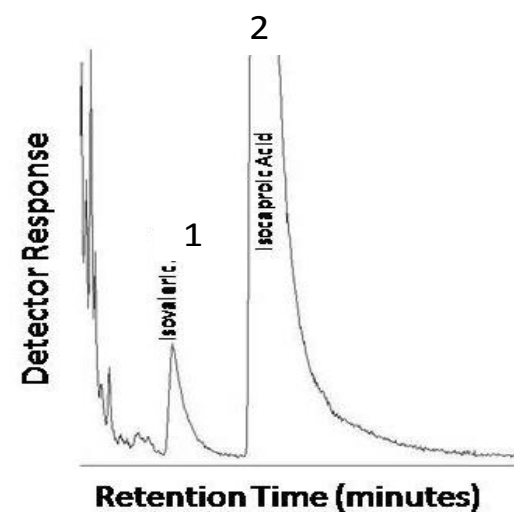

B

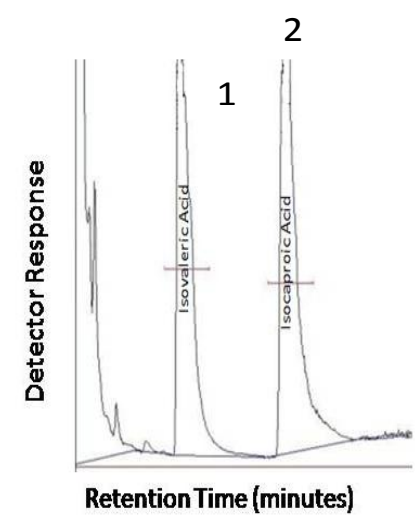

C

Figure 1. Chromatogram for standard volatile fatty acids (a), standard strain of $C$. difficile (b) and representative of isolated $C$. difficile (c).1: Isovaleric acid, 2: Isocaproic acid.

genotypes I (57.1\%), II (7.2\%) and IX (35.7\%) were detected. Of the 18 isolates of $C$. difficile obtained from staff and typed by AP-PCR, four genotypes of I (38.9\%),
IV (22.2\%), V (27.8\%), and VI (11.1\%) were recognized. Genotype I was the most isolated one among environmental and staff isolates. Five genotypes of I, IV, $\mathrm{VI}$, VII and XI were obtained from 16 isolates of asymptomatic patients at first day of admission. In addition to these genotypes, one more genotype was isolated from the same patients after 7 days of hospitalization (genotype III). Amongst six acquired $C$. difficile after 7 days of hospitalization 3 genotypes of III, IV, and I were observed in which $50 \%$ of them was type I. Type IV was mostly imported by newly admitted patients to hospital. Eight genotypes were recovered from $14 \mathrm{C}$. difficile of symptomatic patients in which genotype VIII (28.6\%) was the most isolated one and was not obtained from any other C. difficile isolates. Genotype I with 1000 bp was the most dominant in all 84 C.difficile and exhibited among all samples (Table 1).

\section{DISCUSSION}

Outbreaks of nosocomial disease caused by $C$. difficile are relatively common in many hospitals of developed and developing countries (Fawley and Wilcox, 2001; Titov et al., 2000). Laboratory diagnosis of antibiotic associated diarrhea or pseudomembranous colitis requires the isolation of $C$ difficile and the detection of its cytotoxin in the fecal specimen. Laboratory facilities and technical expertise for cell culture are needed, which is also more time consuming. Gas-liquid chromatography is a more rapid and simpler technique and widely is used in bacteriology laboratories to identify anaerobes and to detect their metabolic products directly in clinical specimens. Detection of $C$. difficile by GLC has been reported by microbiology laboratories at different times (Johnson et al., 1989; Pepersack et al., 1983). A high sensitivity (99.6\%) and specificity (99\%) of GLC in detecting isocaproic and isovaleric acids produced by $C$. difficile in a mixed culture medium has been reported (Johnson et al., 1989) which had a high consistency with the results obtained for identifying of $C$. difficile in our study.

Several typing systems have been described for this microorganism (Brazier, 2001) but AP- PCR has been used by many researches. Williams et al. (1990) showed AP-PCR potentiality as an effective typing system for plants and bacteria. Fawley et al. (2005) used AP-PCR as a tool for typing $C$. difficile. Several scientists to type other organisms (Mahenthiralingam et al., 1996) have also carried out this method. In our study all 84 isolates were separated into 12 types which are much higher than the results reported by Titov et al. (2000) (five types) and Fawley et al. (2005) (six types) but lower than the 17 APPCR types obtained by Fawley et al. (2005). Sampling from 10 wards with different specialties can be the reason for recovery of 12 types. Acquisition of $C$. difficile during hospitalization varies widely. In our study, $12 \%$ of hospitalized patients acquired $C$. difficile after seven days 
Table 1. AP- PCR types of $C$. difficile isolated from patients, staff, and hospital environments.

\begin{tabular}{|c|c|c|c|c|c|c|}
\hline \multirow[b]{2}{*}{$\begin{array}{l}\text { AP-PCR } \\
\text { type }\end{array}$} & \multicolumn{5}{|c|}{ No. of isolates/total no. (\%) } & \multirow[b]{2}{*}{ Total (\%) } \\
\hline & $\begin{array}{l}\text { Symptomat } \\
\text { ic patients }\end{array}$ & $\begin{array}{c}\text { Asymptomatic patients } \\
\text { at first day of } \\
\text { admission }\end{array}$ & $\begin{array}{c}\text { Asymptomatic } \\
\text { patients after seven } \\
\text { days of hospitalization }\end{array}$ & Staff & $\begin{array}{c}\text { Hospital } \\
\text { environments }\end{array}$ & \\
\hline I & $2 / 14(14.3)$ & $3 / 16(18.8)$ & $\left({ }^{* *} 3+3\right) / 22(27.3)$ & 7/18(38.9) & $8 / 14(57.1)$ & $26(31)$ \\
\hline II & ${ }^{*} \mathrm{NI}$ & $\mathrm{NI}$ & $\mathrm{NI}$ & $\mathrm{NI}$ & $1 / 14(7.2)$ & $1(1.2)$ \\
\hline III & $\mathrm{NI}$ & $\mathrm{NI}$ & $1 / 22(4.5)$ & $\mathrm{NI}$ & $\mathrm{NI}$ & $1(1.2)$ \\
\hline IV & $\mathrm{NI}$ & $5 / 16(31.2)$ & $(2+5) / 22(31.8)$ & 4/18(22.2) & $\mathrm{NI}$ & $16(19.1)$ \\
\hline V & 2/14 (14.3) & $\mathrm{NI}$ & $\mathrm{NI}$ & $5 / 18(27.8)$ & $\mathrm{NI}$ & $7(8.3)$ \\
\hline VI & 2/14 (14.3) & $1 / 16(6.2)$ & $1 / 22(4.5)$ & 2/18(11.1) & $\mathrm{NI}$ & $6(7.1)$ \\
\hline VII & $1 / 14(7.1)$ & 3/16 (18.8) & 3/22 (13.7) & $\mathrm{NI}$ & $\mathrm{NI}$ & $7(8.3)$ \\
\hline VIII & 4/14 (28.6) & $\mathrm{NI}$ & $\mathrm{NI}$ & $\mathrm{NI}$ & $\mathrm{NI}$ & $4(4.8)$ \\
\hline IX & $1 / 14(7.1)$ & $\mathrm{NI}$ & $\mathrm{NI}$ & $\mathrm{NI}$ & $5 / 14(35.7)$ & $6(7.1)$ \\
\hline$x$ & $1 / 14(7.1)$ & $\mathrm{NI}$ & $\mathrm{NI}$ & $\mathrm{NI}$ & $\mathrm{NI}$ & $1(1.2)$ \\
\hline$X I$ & $\mathrm{NI}$ & $4 / 16(25)$ & 4/22 (18.2) & $\mathrm{NI}$ & $\mathrm{NI}$ & $8(9.5)$ \\
\hline XII & $1 / 14(7.1)$ & $\mathrm{NI}$ & $\mathrm{NI}$ & $\mathrm{NI}$ & $\mathrm{NI}$ & $1(1.2)$ \\
\hline 12 & $14 / 14(100)$ & $16 / 16(100)$ & $22 / 22(100)$ & $18 / 18(100)$ & $14 / 14(100)$ & $84 / 84(100)$ \\
\hline
\end{tabular}

${ }^{*} \mathrm{NI}$ : Not isolated.

${ }^{* *} \mathrm{Hospital}$ acquired isolates are shown in bold numbers.

while other researchers reported 16.9 and $9.5 \%$ of patients with nosocomial diarrhea had positive infections by $C$. difficile respectively (Rotimi et al., 2002; Sansone et al., 2009). Eleven percent of $C$. difficile acquisition within $72 \mathrm{~h}$ after admission to wards was also reported (Samore et al., 1994), considering the period of hospitalization it is much higher than the results we obtained. Patient-topatient or staff to patient transmission of $C$. difficile was evidenced by incident cases with identical AP-PCR types IV, V, VI, and VII. The presence of these genotypes in the staff and infected patients and absence of those genotypes in the environment over this period implies patient-to-patient and/or staff-to-patient spread.

The dominant type I isolated from all $C$. difficile showed extensive spread of this type among all groups of patients and environment. The type AP- PCR III C. difficile $1 / 22$ $(4.5 \%)$ was isolated from the patients after seven days of hospitalization on only one occasion during the period of study. However, this type was not isolated from samples obtained from environments of wards, staff, asymptomatic patients at first day of admission, and symptomatic patients. Thus, the source of $C$. difficile APPCR III isolated from the patient after seven days of hospitalization remains unclear. This may have been introduced by an asymptomatic carrier, via the hands of visitors, or possibly, from an infected patient whose fecal isolate was not available for analysis. Similar to the findings of Fawley et al. (2005) only two types IX and I were identified as causing both patient infection and ward contamination that indicates transmission of $C$. difficile from patient to environment and vice verse. Attempts to determine whether infected patients or contaminated environments are the prime source for cross-infection by
C. difficile had limited success. Some research reported 18 and $10.25 \%$ of patients to be stool culture positive at admission to wards, suggesting that $C$. difficile-colonized new admissions are a major source of nosocomial $C$. difficile infection (Clabots et al., 1992; Samore et al., 1994). In our study $32 \%$, of patients admitted to the wards were $C$. difficile positive, among which type XI was imported to the hospital only by admission of new patients. Indiscriminate consumption of antibiotics by patients and people can be the main factor in overgrowth of $C$. difficile among new admitted patients. Types VIII, $\mathrm{X}$ and XII were detected only from symptomatic patients and type II was found only in hospital environment.

\section{Conclusion}

The results indicate that nosocomial $C$. difficile infection associated with diarrhea is frequently transmitted among hospitalized patients and that the organism is often present on the hospital environment and personnel caring for such patients. Effective preventive measures are needed to reduce nosocomial acquisition of $C$. difficile.

\section{ACKNOWLEDGMENT}

We express our sincere thanks to vice research chancellor of Tabriz University of medical sciences for financial support of this research (5/4/8748-2009/1/30). We also thank Magsoud Shaker for expert assistance in the performance GLC and Majid godraty for his cooperation in collecting samples from the hospital. This 

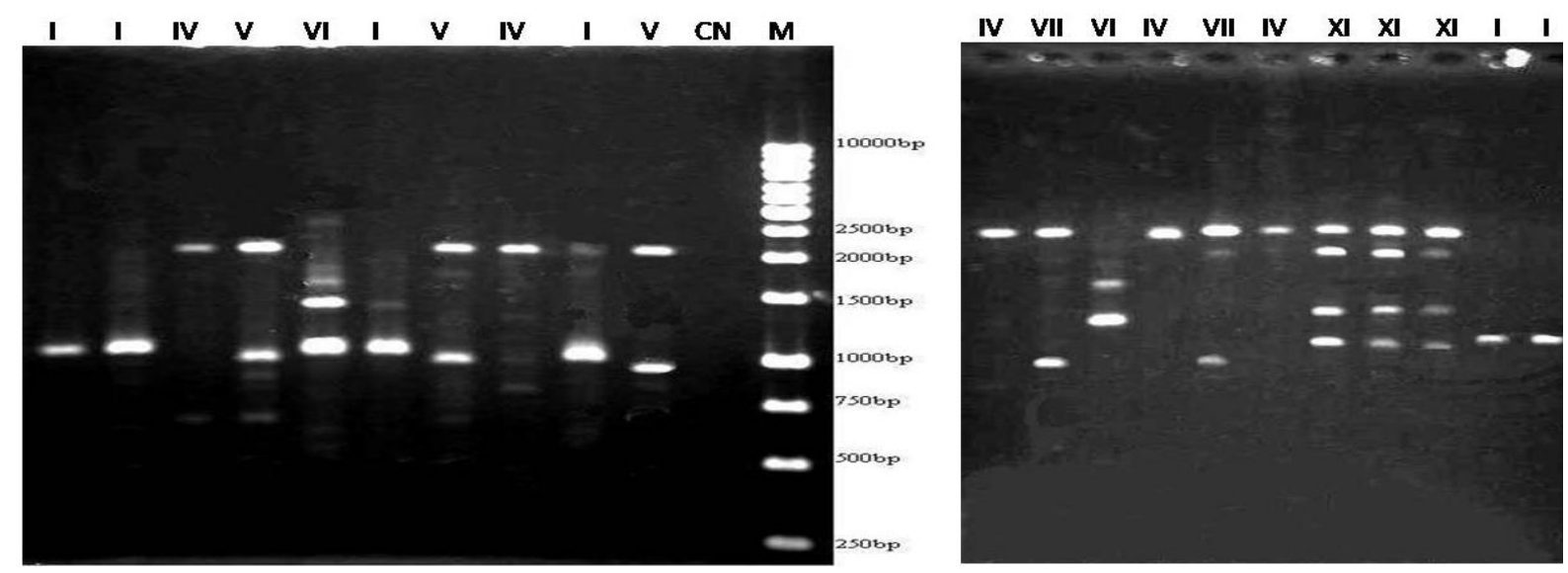

A

B

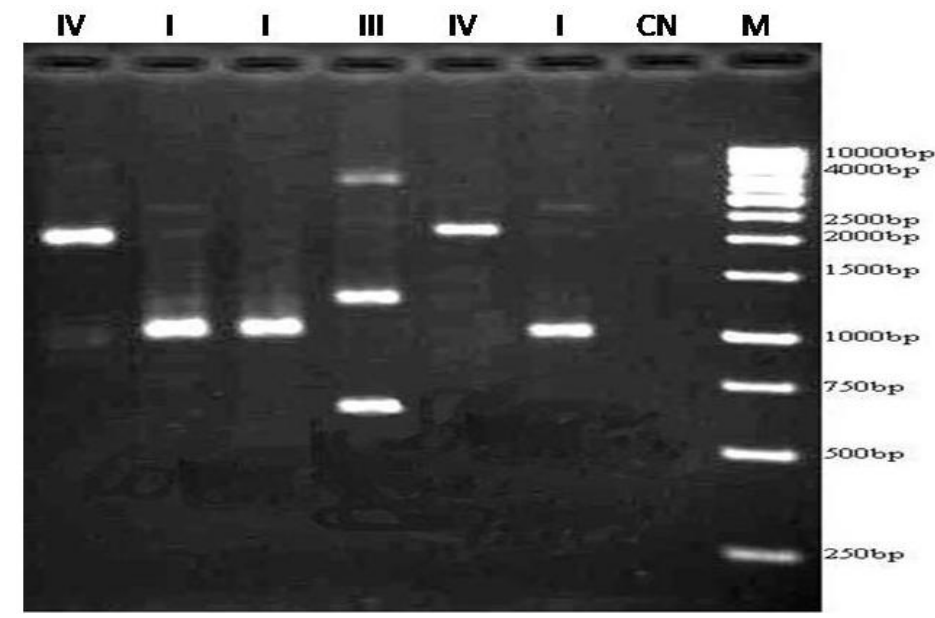

I VIII IX VI VIII VII VI I XII V VIII VIII V

C
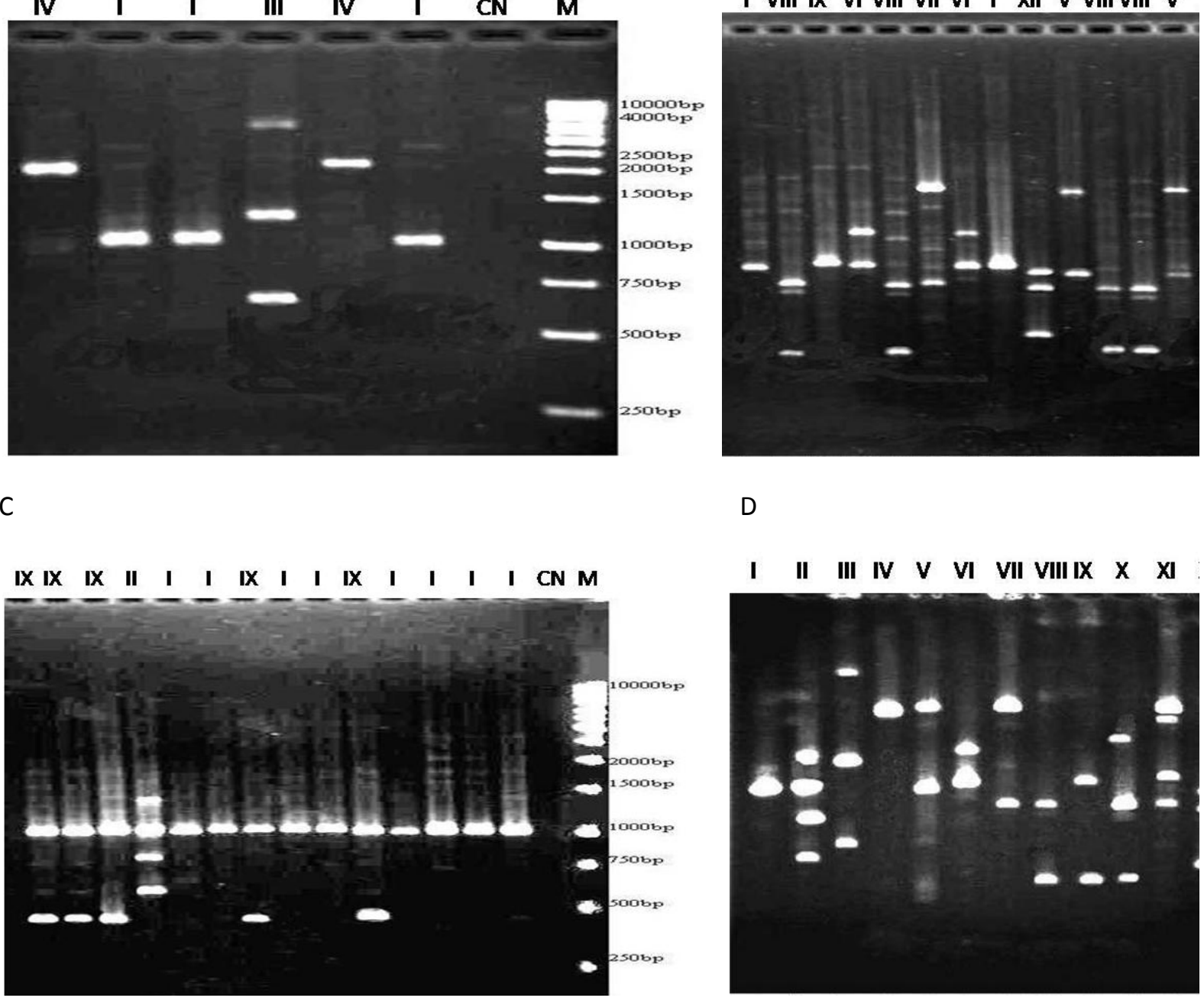

$\mathrm{E}$

$\mathrm{F}$

Figure 2. Typing of $C$. difficile isolates from different sources using AP-PCR technique: (a) hospital staff; (b) asymptomatic patients at first day of admission; (c) the same patients after seven days of admission (acquired); (d) symptomatic patients; (e) hospital environment; (f) representative of each genotypes obtained from all 84 isolates. M: 1 Kbp ladder, CN: negative PCR control; I to XII: different genotypes obtained. 
research was approved by the committee of ethics on research of the Tabriz University of Medical Sciences $(5 / 4 / 8265-2009 / 1 / 16)$.

\section{REFERENCES}

Akhi MT, Pirzade T, Naghili B, Gojazade M (2011). Antimicrobial susceptibility of Clostridium difficile isolated from different sources of Imam Reza Hospital, Tabriz. Afr. J. Microbiol. Res. 5(19):2946-2949.

Bidet P, Lalande V, Salauze B, Burghoffer B, Avesani V, Delmee M, Rossier A, Barbut F, Petit JC (2000). Comparison of PCR-ribotyping, arbitrarily primed PCR, and pulsed-field gel electrophoresis for typing Clostridium difficile. J. Clin. Microbiol. 38(7):2484-2487.

Boyce JM (2007). Environmental contamination makes an important contribution to hospital infection. J. Hosp. Infect. 65:50-54.

Brazier JS (2001). Typing of Clostridium difficile. Clin. Microbiol. Infect. 7(8):428-431.

Clabots CR, Johnson S, Olson MM, Peterson LR, Gerding DN (1992). Acquisition of Clostridium difficile by hospitalized patients: evidence for colonized new admissions as a source of infection. J. Infect. Dis. 166(3):561-7.

Conly J (2000). Clostridium difficile-associated diarrhea - the new scourge of the health care facility. Can. J. Infect. Dis. 11:25-27.

Fawley WN, Parnell P, Verity P, Freeman J, Wilcox MH (2005). Molecular epidemiology of endemic Clostridium difficile infection and the significance of subtypes of the United Kingdom epidemic strain (PCR ribotype 1). J. Clin. Microbiol. 43(6):2685-2696.

Fawley WN, Wilcox MH (2001). Molecular epidemiology of endemic $C$. difficile infection. Epidemiol. Infect. 126(3):343-350.

Hota B (2004). Contamination, disinfection, and cross-colonization: are hospital surfaces reservoirs for nosocomial infection? Clin. Infect. Dis. 39:1182-1189.

Johnson LL, McFarland LV, Dearing P, Raisys V, Schoenknecht FD (1989). Identification of Clostridium difficile in stool specimens by culture-enhanced gas-liquid chromatography. J. Clin. Microbiol. 27:2218-2221.

Killgore GE, Kato H (1994). Use of arbitrary primer PCR to type Clostridium difficile and comparison of results with those by immunoblot typing. J. Clin. Microbiol. 32(6):1591-1593.

Kim KH, Fekety R, Batts DH, Brown D, Cudmore M, Silva J Jr, Waters D (1981). Isolation of Clostridium difficile from the environment and contacts of patients with antibiotic-associated colitis. J. Infect. Dis. 143(1):42-50.

Mahenthiralingam E, Campbell ME, Foster J, Lam JS, Speert DP (1996). Random amplified polymorphic DNA typing of Pseudomonas aeruginosa isolates recovered from patients with cystic fibrosis. J. Clin. Microbiol. 34(5):1129-1135.

Martirosian G, Kuipers S, Verbrugh H, van BA, Meisel-Mikolajczyk F (1995). PCR ribotyping and arbitrarily primed PCR for typing strains of Clostridium difficile from a Polish maternity hospital. J. Clin. Microbiol. 33(8):2016-2021.
Mayfield JL, Leet T, Miller J, Mundy LM (2000). Environmental control to reduce transmission of Clostridium difficile. Clin. Infect. Dis. 31(4):995-1000.

Muto CA (2007). Asymptomatic Clostridium difficile colonization: is this the tip of another iceberg? Clin. Infect. Dis. 45:999-1000.

Nikbakht M, Nahaei MR, Akhi MT, Asgharzadeh M, Nikvash S (2008). Molecular fingerprinting of meticillin-resistant Staphylococcus aureus strains isolated from patients and staff of two Iranian hospitals. J. Hosp. Infect. 69(1):46-55.

Noren T (2010). Clostridium difficile and the disease it causes. Methods Mol. Biol. 646:9-35.

Pepersack F, Labbe M, Nonhoff C, Schoutens E (1983). Use of gasliquid chromatography as a screening test for toxigenic Clostridium difficile in diarrhoeal stools. J. Clin. Pathol. 36(11):1233-1236.

Rafferty ME, Baltch AL, Smith RP, Bopp LH, Rheal C, Tenover FC, Killgore GE, Lyerly DM, Wilkins TD, Schoonmaker DJ, Hannett GE, Shayegani M (1998). Comparison of restriction enzyme analysis, arbitrarily primed PCR, and protein profile analysis typing for epidemiologic investigation of an ongoing Clostridium difficile outbreak. J. Clin. Microbiol. 36(10):2957-2963.

Roberts K, Smith CF, Snelling AM, Kerr KG, Banfield KR, Sleigh PA, Beggs CB (2008). Aerial dissemination of Clostridium difficile spores. BMC Infect. Dis. 8:7.

Rotimi VO, Mokaddas EM, Jamal WY, Verghese TL, El-Din K, Junaid TA (2002). Hospital-Acquired Clostridium difficile Infection amongst ICU and Burn Patients in Kuwait. Med. Princ. Pract. 11:23-28.

Samore MH, DeGirolami PC, Tlucko A, Lichtenberg DA, Melvin ZA, Karchmer AW (1994). Clostridium difficile colonization and diarrhea at a tertiary care hospital. Clin. Infect. Dis. 18(2):181-7.

Sansone S, Aschbacher R, Staffler M, Bombonato M, Girardi F, Larcher C, Wiedermann CJ (2009). Nosocomial diarrhoea in adult medical patients: the role of Clostridium difficile in a North Italian acute care teaching hospital. J. Prev. Med. Hyg. 50(2):117-20.

Titov L, Lebedkova N, Shabanov A, Tang YJ, Cohen SH, Silva J Jr (2000). Isolation and molecular characterization of Clostridium difficile strains from patients and the hospital environment in Belarus. J. Clin. Microbiol. 38(3):1200-2.

Williams JG, Kubelik AR, Livak KJ, Rafalski JA, Tingey SV (1990). DNA polymorphisms amplified by arbitrary primers are useful as genetic markers. Nucl. Acids Res. 18(22):6531-6535. 